\title{
Economic Uncertainty and Money Demand Stability in Uganda during Financial Liberalization: A GARCH and ARDL Approach
}

\author{
Allan Kayongo ${ }^{1} \&$ Asumani Guloba ${ }^{1}$ \\ ${ }^{1}$ Policy Research and Innovation Department, National Planning Authority; Kampala, Uganda \\ Correspondence: Allan Kayongo, Policy Research and Innovation Department, National Planning Authority; Kampala, \\ Uganda.
}

Received: May 13, 2018

doi:10.11114/aef.v5i4.3271

\author{
Accepted: June 6, $2018 \quad$ Available online: June 12, 2018 \\ URL: https://doi.org/10.11114/aef.v5i4.3271
}

\begin{abstract}
$^{1}$
This paper examines the impact of economic uncertainty on money demand stability in Uganda during financial liberalization. First, an economic uncertainty index is created using the Generalized autoregressive conditional heteroscedasticity $(G A R C H)$ method to measure uncertainty. Secondly, the Autoregressive Distributed Lag (ARDL) methodology is used to estimate three risk-augmented monetary aggregates: base money, broad money $M 2$ and broad money $M 3$. The results show that economic uncertainty has no effect on real base money and real broad money $M 2$ in the short run; but has a negative effect on real broad money $M 3$. However, economic uncertainty negatively affects all monetary aggregates after one quarter. This is because economic agents diversify their portfolio from just holding money, into other forms like: long term accounts; foreign accounts; treasury bills and bonds; property; mortgages and land. The three money demand balances are also stable.
\end{abstract}

Keywords: economic uncertainty, money demand stability, financial innovations

JEL Classification: E41; E52; E6

\section{Introduction}

The stability of the money demand function is important in the design and implementation of monetary policy. A stable money demand function has long been considered as a requirement for effective use of monetary aggregates in the conduct of monetary policy (El-Rasheed, Abdullah \& Dahalan, 2017; Friedman \& Schwartz, 1982; Goldman \& Sichel 1990). The money demand function helps in establishing the link between monetary aggregates and the national income (Laidler, 2013). This is particularly true in the presence of significant volatilities in the various components of monetary aggregates (El-Rasheed et al., 2017).

There was generally a shift from money as a guide of monetary policy to interest rates especially during the start of the 1990s; however, this debate has been reinvigorated in the aftermath of the financial crisis around private actors' liquidity preference as a major determinant of money demand. A high liquidity preference has caused a risk of protracted periods of stagnation for the world economy (Bossone, 2014; Eggertsson \& Mehrotra, 2014). This is because quantitative easing policies exercised by central banks lead to money growth rates which are incompatible with real growth rates and therefore raising concerns about future inflation (Groessl \& Tarassow, 2015). Previously emphasis was put on stable relationship between money demand and income yet current concerns illuminate future inflation brought about by excessive monetary growth. This emphasizes attention on how expected inflation and its volatility affect money holdings in the non-bank sector. A negative correlation between both variables and money demand implies that the non-bank sector wants to rid itself from high money holdings thus boosting purchases of goods and assets (Groessl \& Tarassow, 2015).

Stagnation worries advocate for the need to understand how risks might affect actors' liquidity preference. The most prominent fear is that people do not believe in inflation but are instead afraid of lasting deflationary forces (Groessl \& Tarassow, 2015). Increased monetary uncertainty would make rational economic agents to move their assets away from

\footnotetext{
${ }^{1}$ Disclaimer: The views expressed in this paper are those of the authors and do not necessarily reflect the Position and Policies of the NPA Executive Board and those of the Executive Director.
} 
cash holding to less volatile assets such as real assets (El-Rasheed et al., 2017). More so, a rise in monetary uncertainty would make agents more careful about the future thereby keeping more cash today. Therefore, economic uncertainty affects both consumption and investment decisions; and decisions of households, businesses, policy makers and financial intermediaries (Anderson, Bordo \& Duca, 2016; Bloom, 2009). This therefore suggests that incorporating uncertainty in money demand forecasts will play a pivotal role for both the assessment of the future macroeconomic development and for the effectiveness of Uganda's monetary policy.

Several East African, and Uganda specific studies capture the impact of financial innovation on money demand and the economy at large but they have failed to incorporate economic uncertainty and its impact on the economy (Ndirangu \& Nyamongo, 2015; Nyorekwa, 2007). Many of these studies focus on money being a function of a scale variable, and other opportunity cost variables in the absence of economic uncertainty (Guloba \& Osoro, 2009; Kararach, 2002; Opolot, 2007; and Nabiddo, 2007). Except Kiptui (2014), studies on the impact of economic uncertainty on money demand are non-existent for the East Africa region and Uganda in particular. Further, studies that have attempted to reflect economic uncertainty have yielded mixed results. Some studies have found that monetary uncertainty affects money demand in the short-run (Bahmani-Oskooee, Ali \& Xi, 2013; Greiber \& Lemke, 2005) while others conclude that macroeconomic uncertainty has both short and long run impact on the money demand function (Attah-Mensah, 2004; Bahmani-Oskooee et al., 2013; Ozdemir \& Saygili, 2013). Others (Bruggeman, Donati \& Warner, 2003) conclude that neither output nor money uncertainty have any impact on the money demand function. There have also been methodological differences; for instance, Bahmani- Oskooee, Bahmani, Kones and Kutan et al. (2015) find that the limited studies that have assessed the impact of economic uncertainty on the demand for money have concentrated on using a volatility measure of money supply and output. Certainly, other factors such as regulation, taxes, budget deficits, national debt, etc. can contribute to an uncertain environment.

Uganda presents an interesting case in the analysis between economic uncertainty and money demand. Uganda has seen monetary tightening in the face of inflationary conditions and loosening during the periods of recessionary conditions; this has seen the Central Bank Rate ( $C B R$ ) drop from 18 to 9 percent currently. Bank of Uganda (2017) reports that growth in bank deposits declined by 2.6 percent in 2016, reflecting weak economic activity. By December, 2016; customers' deposits accounted for 81.1 percent of the total liabilities of the total liabilities of the banking sector. Wholesale funding reduced during 2016, accounting for 3 percent of the total liabilities of the banking sector. The total shareholders' equity of the banking system grew by only 1.9 percent from Ushs. 3.6 trillion to Ushs. 3.7 trillion in 2016. This was lower than 12.6 per cent growth rate in the previous year. The slow growth in equity is due to banks' subdued capital generation from retained reserves during 2016. Retained reserves in the bank increased by 9.1 percent in 2016 compared to 23.2 percent in 2015.

Therefore, assessing the relationship between economic uncertainty and Uganda's money demand is important especially during the era of financial liberalization and innovations. The paper is the first of its kind to assess the impact of economic uncertainty in Uganda and among the first in East Africa. It uses the Generalized equilibrium models instead of the usual money demand models to incorporate uncertainty in Uganda's money demand during financial liberalization.. It employs $G A R C H$ to create an economic uncertainty index and the $A R D L$ methodology to estimate uncertainty augmented money demand functions. This paper will contribute to the debate on the appropriate Uganda's monetary policy management. More specifically, the paper seeks to find out the determinants of money demand in Uganda; find the impact of economic uncertainty on money demand and assess the stability of Uganda's money demand during 2001Q4 to 2017Q2.

The rest of the paper is structured as: Section Two, presents the literature regarding the impact of uncertainty on money demand; Section Three presents the theoretical stipulations of money demand based on the Generalized equilibrium, GARCH and ARDL methodology; Section Four presents the data qualities while Section Five presents the paper's results and interprets the intuition behind them. Lastly, Section Six concludes and provides policy insights.

\section{Literature}

\subsection{Risk Factors and Money Demand}

The impact of uncertainty on money, liquidity and unemployment in a market economy depends on the concept that is chosen between the Classical concept and the Keynesian concept (Davidson, 1999). Early economists assumed the world to be perfectly certain with all households and businesses possessing full and correct knowledge about economic activity (Davidson, 1999; Ricardo, 1817). However, Classical economists substituted probabilistic risk premia for perfect knowledge assumption. By 1970's, the classical risk premia had evolved into the rational expectations where individuals made decisions based on the subjective probability distribution that are presented to be equal to immutable objective probability distribution (Lucas, 1972). It is further argued that currently, uncertainty is interpreted as synonymous with objective probability distribution at given future events but completely known to all persons today (Lucas, 1972; Machina, 1989). The quantitative measure of uncertainty is the standard deviation. 
When consumers face a stochastic income stream, higher uncertainty about the future induces precautionary saving by risk-averse households; additionally, increase in uncertainty also depresses output, consumption, investment and hours worked, particularly in the presence of non-convex costs of adjustment (Basu \& Bundick, 2015; Bloom, 2009). However, it is argued that in a general-equilibrium neoclassical model with a representative firm and a consumer with additively time-separable preferences, the previous intuition doesn't hold. Although standard general-equilibrium models with flexible prices fail to reproduce this correlation, uncertainty shocks can easily generate this correlation with countercyclical mark-ups through sticky prices. It is also argued that monetary policy is key in offsetting the negative impact of uncertainty shocks during normal times.

The effect of uncertainty on money demand has both demand and supply effects. Theory suggests that economic uncertainty may affect the economy's demand side through its impact on household consumption or firm investment. Also, there are various supply side channels through which economic uncertainty may have repercussions on the economy (Bloom, 2009; Bloom, Kose \& Terrone, 2013).

The empirical findings on the effects of economic uncertainty on monetary policy are inconclusive, that is: economic uncertainty can have a positive effect; negative effect; both positive and negative effects; or no significant effect on money demand. Studies that contend that uncertainty has a positive effect on money demand argue that this is the case because economic agents substitute their asset holdings to safe alternatives like cash in the presence of risky uncertainties (Anderson et al, 2016; Atta-Mensah, 2004; Carpenter \& Lange, 2003; Choi and Oh, 2003 among others). However, others contend that economic uncertainty has a negative impact on money demand (Higgins and Manjin, 2009; Nazar, Farshid \& Davood, 2011; Tillman, 2017). They argue that economic uncertainty reduces money holdings as agents transform their nominal assets to other long-term assets with a view that money is less predictable. Intermittently, while monetary uncertainty changes money demand, monetary uncertainty may be caused by excessive money growth as well (Cronin \& Kennedy, 2007). In other instances, uncertainty has both positive wealth and negative substitution effects on money demand (Anderson et al., 2016). However, there also exists studies that conclude that there are no significant contemporaneous effects between economic uncertainty and money demand (Bruggerman et al., 2003; Leippold \& Matthys, 2015). Some attribute this to the estimation period especially if the period chosen doesn't cover pronounced periods of stock market volatility (Bruggerman et al., 2003).

There also exist methodological differences in the empirical studies that have explored economic uncertainty effects on money demand. The empirical literature shows that money demand is majorly theoretically specified using the general specification where money is estimated as a function of a scale and opportunity cost variables (Guloba \& Osoro, 2009; Ndirangu \& Nyamongo, 2015) while a few others use the general equilibrium model which is micro-economic founded in nature (Attah-Mensah, 2004; Choi \& Oh, 2003; Dib, 2003; Ireland, 1997 \& 2001; and Kim, 2000). The methodologies involved in the creation of the economic uncertainty largely involve the use of generalized autoregressive conditional heteroscedasticity $(G A R C H)$ method to extract volatilities from the key determinants of money demand while others use economic uncertainty index databases. Bahmani- Oskooee et al. (2015) explains that the limited studies that have assessed the impact of economic uncertainty on the demand for money have concentrated on using a volatility measure of money supply and output. Certainly, other factors such as regulation, taxes, budget deficits and national debt among others, can contribute to an uncertain economic environment. The other variables usually involved in the money demand estimations include: real income, real interest rates, exchange rates, inflation, stock market returns among others. The estimation methods largely involve cointegration methods of $O L S, V A R, A R D L$ and rolling window dynamic multiplier estimations methods. VECM methods of these estimations are often used to estimate the short run effects of economic uncertainty on money demand.

Stability tests largely conclude that money demand estimations are stable. However, while some conclude that monetary uncertainty affects money demand stability in the short-run (Bahmani-Oskooee et al., 2013; Greiber \& Lemke, 2005), others conclude that macroeconomic uncertainty has both short and long run impact on the money demand function (Attah-Mensah, 2004; Bahmani-Oskooee et al., 2013; Ozdemir \& Saygili, 2013). By implication, the monetary policies aimed at monetary targeting could be very effective even in the presence of significant monetary uncertainty (Atta-Mensah, 2004). Additionally, economic uncertainty affects different monetary aggregates differently (Atta-Mensah, 2004); that is, it may increase demand for smaller monetary aggregates and reduce demand for larger monetary aggregates or vice-versa.

A majority of empirical literature regarding economic uncertainty and money demand is on developed countries especially Euro Area and USA (Anderson et al, 2016; Atta-Mensah, 2004; Carpenter \& Lange, 2003; Carstensen, Hagen, Hossfield \& Neaves, 2008; Choi \& Oh, 2003; Groessl \& Tarassow, 2015). Very few studies therefore have been done on developing countries or Africa (Kiptui, 2014; Kones, 2014; Nazar et al., 2011)and none for Uganda in particular. Kiptui (2014) included an uncertainty variable in the estimation of Kenya's money demand; the study measured volatilities from exchange rate, interest rates, inflation and the Nairobi stock market share price index using the GARCH 
methodology. They also concluded like (Ozdemir \& Saygili, 2013) that using a single measure of uncertainty is sufficient to capture uncertainty in the economy since variables are highly correlated to each other.

Therefore, this paper is an attempt to fill the gap in literature to empirically investigate the effect of economic uncertainty on money demand in Uganda and East Africa in general. The paper uses the general equilibrium framework of money demand to estimate the effects of the economic uncertainty on money demand. The study employs GARCH to create an economic uncertainty index and thereafter the $A R D L$ method to estimate Uganda's money demand functions. The paper specifies other determinants of money demand as income, inflation, exchange rate, interest rate spread, foreign interest rate and financial innovations. The study also estimates the stability of three monetary aggregates; base money, broad money M2 and broad money M3 during the financial liberalized period 2001 Q4 to 2017Q2.

\section{Methodology}

\subsection{Money Demand Derivation Using General Equilibrium Framework}

The paper adopts the general equilibrium framework similar to (Atta-Mensah, 2004; Choi \& Oh, 2003; Dib, 2003; Ireland, 1997 \& 2001; and Kim, 2000). The choice of this over the standard money demand theoretical stipulation is two-fold, i.e.; money is held because it provides utility; and money demand is not only affected by its determinants but also by the volatilities that affect its determinants (Lioui \& Poncet, 2004). The economy is made up of four representative agents: a household, a finished-goods-producing firm, an intermediate-goods producing firm, and a monetary authority. In this economy, the finished goods are sold to households and to an intermediate-goods-producing firm at a perfectly competitive price, $p_{t}$. Each intermediate-goods-producing firm produces its output with labour and capital supplied by households, and the output is sold on a monopolistically competitive market. Additionally, the representative household's preferences in this economy are defined over consumption of the finished good, leisure, and real money balances. Focusing on the optimization decision of the representative household, this section derives a conventional money demand function.

The representative household maximizes its utility by choosing consumption, $C_{t}$, real money balances, and leisure, $\left(1-h_{t}\right)$. The preference function of the household is summarized by the expected utility function of the form:

$$
U_{0}=E_{0} \beta_{t}\left[\frac{\gamma}{\gamma-1} \log \left(c_{t}^{\frac{\gamma-1}{\gamma}}+b_{t}^{\frac{1}{\gamma}}\left(\frac{M_{t}}{p_{t}}\right)^{\frac{\gamma-1}{\gamma}}\right)+\mu \log \left(1-h_{t}\right)\right]
$$

with $\beta \in(0,1)$ is the discount factor, $\gamma$ and $\mu$ are positive structural parameters, $M_{t}$ is the total money balance in the economy, and $h_{t}$ are the labour hours. $b_{t}$ summarizes the money-demand shocks and is assumed to evolve as:

$$
\log \left(b_{t}\right)=\left(1-\rho_{b}\right) \log b+\rho_{b} \log \left(b_{t-1}\right)+e_{b t}
$$

with $e_{b t}$ being the serially uncorrelated shock which is normally distributed with mean of zero and a standard deviation of $\delta_{b}$ and $\rho_{b} \in(-1,1)$.

At the beginning of period $t$, the household holds $k_{t}$ units of capital, $M_{t-1}$ units of money, and $\beta_{t-1}$ units of government discount bonds. The household supplies capital and labour to the intermediate-goods-producing firms in perfectly competitive markets. The amounts supplied to each individual intermediate firm, $j$, are given by $k_{j t}$ and $h_{j t}$, where $j \in[-1,1]$. Therefore, aggregate capital and aggregate labour satisfy $k_{t}=\int_{0}^{1} k_{j t} d_{j}$ and $h_{t}=\int_{0}^{1} h_{j t} d_{j}$, for all $t$. The household derives its income from rent from capital, labour income, dividends from intermediate goods producing firms, $D_{t}=\int_{0}^{1} D_{j t} d_{j}$, and a lumpsum nominal transfer, $T_{t}$, from the monetary authority, from the monetary authority. From its income, the household purchases output from the finished-goods-producing firm at the price $p_{t}$, part of which it consumes while the remainder is invested. Capital in the economy accumulate as follows;

$$
k_{t+1}=(1-\delta) k_{t}+i_{t}
$$

with $i_{t}$ representing investment and $\delta \in(0,1)$ is a constant capital depreciation rate.

Assuming $R_{t}$ is the nominal interest rate (Government bond return) between periods $t$ and $+1, r_{k t}$; is the real rental rate of capital, and $w_{t}$ the real wage. The household's budget constraint is:

$$
c_{t}+k_{t+1}-(1-\delta) k_{t}+\frac{M_{t}{ }^{B_{t}} / R_{t}}{p_{t}} \leq \frac{r_{k t} k_{t}+w_{t} h_{t}+M_{t-1}+B_{t-1}+T_{t}+D_{t}}{p_{t}}
$$

In each period $t=0,1,2 \ldots$, the household chooses $c_{t}, h_{t}, M_{t}, B_{t}$, and $k_{t+1}$, to maximize the utility function given by equation (1) subject to equation (4). Assuming $\lambda_{t}$, is the Langrarian multiplier, the first order conditions for the household's maximization problems are; 


$$
\begin{aligned}
& \frac{c_{t}^{-\frac{1}{\gamma}}}{c_{t}^{\frac{\gamma-1}{\gamma}}+b_{t}^{\frac{1}{\gamma}}\left(M_{t} / p_{t}\right)^{\frac{\gamma-1}{\gamma}}}-\lambda_{t}=0 \\
& \frac{\mu}{1-h_{t}}-\lambda_{t} w_{t}=0 \\
& \frac{b_{t}^{\frac{1}{\gamma}}\left(M_{t} / p_{t}\right)^{-\frac{1}{\gamma}}}{c_{t}^{\frac{\gamma-1}{\gamma}}+b_{t}^{\frac{1}{\gamma}}\left(M_{t} / p_{t}\right)^{\frac{\gamma-1}{\gamma}}}-\lambda_{t}+\beta E_{t}\left(\frac{p_{t} \lambda_{t}+1}{p_{t+1}}\right)=0 \\
& \frac{1}{R_{t}}-\beta E_{t}\left(\frac{p_{t} \lambda_{t}+1}{p_{t+1} \lambda_{t}}\right)=0 \\
& \lambda_{t}-\beta E_{t}\left[\lambda_{t+1}\left(\frac{r_{k t+1}}{p_{t+1}}+1-\delta\right)\right]=0
\end{aligned}
$$

Equations (5) and (6) imply that the marginal rate of substitution between consumption and labour is equal to the real wage. Taking $\lambda_{t}$ as the marginal utility of consumption, equation (8) indicates that the price of the Government discount bond $\left(1 / R_{t}\right)$ is equal to the expected discounted value of the intertemporal marginal rate of substitution for consumption. Equation (9) equates the marginal utility cost of an additional unit of investment during period $t$ with the discounted expected marginal utility value of its return during period $t+1$.

Relying on equation (8), the equation can be expressed as below;

$$
\frac{b_{t}^{\frac{1}{\gamma}}\left(M_{t} / p_{t}\right)^{-\frac{1}{\gamma}}}{c_{t}^{\frac{\gamma-1}{\gamma}}+b_{t}^{\frac{1}{\gamma}}\left(M_{t} / p_{t}\right)^{\frac{\gamma-1}{\gamma}}}=\lambda_{t}\left(1-\frac{1}{R_{t}}\right)
$$

Thereafter, combining equations (6) and (10) yields the equation below (11);

$$
\left(\frac{b_{t} c_{t}}{M_{t} / p_{t}}\right)^{\frac{1}{\gamma}}=1-\frac{1}{R_{t}}
$$

If we let $r_{t}=R_{t}-1$ denote the net nominal interest rate between $t$ and $t+1 ; 1 / R_{t} \approx 1-r_{t}$ can then be approximated and equation (11) becomes as written below;

$$
\log \left(M_{t} / p_{t}\right) \approx \log \left(c_{t}\right)+\gamma \log \left(r_{t}\right)+\log \left(b_{t}\right)
$$

with $\gamma$ representing the interest elasticity of real money demand and $b_{t}$ representing a serially correlated money-demand shock. Equation (12) clearly demonstrates that shocks to the economy have an impact on the quantity of money that economic agents are willing to hold. The source of the money demand shocks could come from a variety of areas in the economy; i.e. monetary and fiscal policies, financial markets, economic activities, and technological changes.

Like (El-Rasheed et al., 2017), this paper postulates that the uncertainties are summarized by $\log (b)$ in equation (2), referred to here as the $n$ index of economic uncertainty. The assumption of unitary income elasticity is relaxed. Additionally, given that consumption is a fraction of income, $c_{t}$ in the equation (12) could be replaced with a measure for income.

\subsection{Measuring Uncertainty}

Estimation of the money demand function requires knowledge about the risks or volatilities of the respective macro-economic variables that cause money demand shocks (Attah-Mensah, 2004). Additionally, risk and uncertainty are taken to be the same and are proxied by a measure of volatility. The six main sources of economic uncertainty are the level of economic activity, inflation, exchange rate, interest rate spread, foreign interest rate and financial innovation. The major thrust of this paper is that the Economic Uncertainty Index $(E U I)$ derived from shocks in these variables 
largely impacts on the money holding decision of economic units. The study also adopts a single uncertainty index because these macro variables are correlated to each other (Kiptui, 2014; Ozdemir \& Saygili, 2013). The economic uncertainty index $(E U I)$ is derived because Uganda doesn't have an official uncertainty indicator as yet.

This paper adopts the common measure of generalized autoregressive conditional heteroscedasticity $(G A R C H)$ model. The GARCH model is chosen over other volatility models because it is: flexible; accurate and provides a unidirectional perspective of the quality of the volatility (Matei, 2009). The GARCH model is based on the notion that the conditional variance of a time series depends upon the squared residuals of the process (Bollerslev, 1986). Heteroscedasticity is introduced to the conditional variance. (Bollerslev et al., 1992) introduce a time-varying conditional variable called $\operatorname{GARCH}(p, q)$. A macroeconomic variable, $y_{t}$, can be modelled as $\operatorname{GARCH}(p, q)$, as follows:

$$
\begin{gathered}
y_{t}=\mu_{t}+\varepsilon_{t} \\
\varepsilon_{t} \mid \Omega_{t} \sim N\left(0, h_{t}\right) \\
h_{t}=\sigma+\sum_{i=0}^{p} \beta_{i} h_{t-1}+\sum_{j=1}^{q} \alpha_{j} \varepsilon_{t-j}^{2}
\end{gathered}
$$

with $\mu_{t}$, representing the mean of $y_{t}$ and conditional on the information set $\Omega_{t-1}$. The following inequality restrictions are imposed on $h_{t}$ to ensure that it is positive. $\sigma>0 ; \beta_{i} \geq 0$; and $\alpha_{j} \geq 0$. The size and significance of $\alpha_{j}$ indicate the presence of an ARCH process in the residuals. This paper relies on $\operatorname{GARCH}(1,1)$ to estimate the conditional variances $h_{t}$. In an Integrated $G A R C H$ i.e. If $\alpha_{1}+\beta_{1}=1$ in a $\operatorname{GARCH}(1,1)$ model; then there will be persistence of the estimated conditional variance over all finite horizons and an infinite variance for the unconditional distribution of $\varepsilon_{t}$ (Engle \& Bollerslev, 1986). Therefore, the current shock persists indefinitely in conditioning the future variance.

The economic uncertainty index $(E U I)$ is constructed as a weighted average of the estimated volatilities with each of the volatilities standardized as the deviation from its mean and divided by the standard deviation. The EUI index is thus calculated as;

$$
E U I=\sum_{i}^{n} \lambda_{i}\left(\frac{\operatorname{vol}_{i}-\overline{v o l}_{i}}{\sigma_{v o l}}\right)
$$

where $v o l_{i}$ is the volatility of the factor that contributes to the source of uncertainty; $\overline{v o l}_{i}$ is the average volatility; $\sigma_{v o l}$ is the standard deviation of volatility; and $\lambda_{i}$ is the weight attached to each factor. The Economic Uncertainty Index is based on the six main sources of economic uncertainty, i.e.; the level of economic activity, inflation, exchange rate, interest rate spread, foreign interest rate and financial innovation. The EUI is constructed based on equation (16). For simplicity, the components of the EUI are weighted equally. Quarterly data are used and the estimation interval is from $2001 Q 4$ to $2017 Q 2$.

\subsection{Money Demand Estimation: An ARDL Approach}

Uganda's money demand is derived based on the theoretical money demand function derived earlier. From equation (12), however, many other crucial variables that affect money demand other than income and interest rate are included into the money demand model. Therefore, Uganda's specific risk-augmented money demand function is expressed as;

$$
\left(\frac{M}{p}\right)_{t}=\alpha_{0}+\alpha_{1} Y_{t}+\alpha_{2} I N F_{t}+\alpha_{3} I R S_{t}+\alpha_{4} E X P_{t}+\alpha_{5} F I R_{t}+\alpha_{6} \operatorname{COB}_{t}+\alpha_{7} E U I_{t}+\varepsilon_{t}
$$

where $(M / p)$ are the real money balances, $Y$ is the real income, INF is the inflation rate, IRS is the interest rate spread between the 91 day Treasury bill rate, and the time and saving deposit rate (this is done by assuming an equal elasticity in absolute terms for the two interest rates); EXP is the exchange rate, FIR is the foreign interest rate, $C O B$ is the measure of financial innovation proxied as currency outside banks to time deposits following (Ndirangu \& Nyamongo, 2015); EUI is the economic uncertainty index and $\varepsilon$ is the error or stochastic term. The paper estimates 3 monetary aggregates i.e.; real base money, real $M 2$ and real $M 3$. Real base money currency in circulation in addition to the demand deposits in banks; $M 2$ is real base money plus saving and time deposits while $M 3$ is $M 2$ plus long-term deposits.

Monetary aggregates are used to proxy for money demand because economic theory stipulates that monetary aggregates are linear and at equilibrium equate money demand. Real income is used as a measure of transactions relating to economic activity and wealth; GDP is specifically used because it aggregates all Uganda's production and therefore signifies its wealth. The interest rate spread between the 91-treasury bill rate and the annual saving and time deposit rate is used to capture the relative interest rate elasticity; it represents the rate of return on a non-monetary financial asset relative to financial assets. Inflation is used because in Uganda, physical goods or assets can be used as a substitution for money and therefore higher inflation causes economic agents to shift their portfolio from money to other physical assets. CPI is specifically used because it reflects the change in prices for a basket of goods and services, generally 
used by the majority of Ugandan households. Exchange rate is used so as to reflect the direct currency substitution effects given that Uganda is an open economy. The exchange rate effect is either a wealth or expectation effect with the wealth effect manifested when economic agents increase the value of foreign securities held with a depreciated of the Ugandan Shilling. On the other hand, a weak Ugandan currency yields expectation for further weakening and therefore asset holders shift some of their portfolio from the domestic currency into a foreign currency.

Foreign interest rate is used so as to reflect the indirect currency substitution; the London Interbank Offered Rate $(L I B O R)$ is specifically used because it is a composite rate of 5 major international currencies; and it is used worldwide by international banks for the interbank operations. The currency to time deposits variable is used as a proxy of financial innovations; this is because financial innovations are expected a priori to cause disequilibrium in money demand stability. A big currency to time deposits ratio signifies that economic agents have a lot of money in circulation and therefore a low level of financial innovations. Conversely, a smaller currency to time deposits ratio reflects that economic agents would rather save their money as time deposits and therefore a high level of financial innovations. The Economic Uncertainty Index $(E U I)$ is also constructed to capture the aspects of the economic uncertainty on money demand as explained earlier.

Expressing money demand as a log linear function;

$$
\ln \left(\frac{M}{P}\right)_{t}=\alpha_{0}+\alpha_{1} \ln Y_{t}+\alpha_{2} I N F_{t}+\alpha_{3} I R S_{t}+\alpha_{4} \ln E X P_{t}+\alpha_{5} F I R_{t}+\alpha_{6} \operatorname{COB}_{t}+\alpha_{7} E U I_{t}+\varepsilon_{t}
$$

The unit root tests are estimated for using ADF; Phillips-Perroni and $D F-G L S$. This is because Auto-Regressive Distributed Lag $(A R D L)$ estimation requires the highest order of integration to be $I$ (1).

The ARDL method as proposed by Pesaran et al. (2001) is used over other co-integration techniques like Engle and Granger (1987); and Johansen and Juselius (1990) because of various reasons i.e. it; can be applied on a small sample size as it happens for this specific paper; is relieved of the order of integration amongst variables; estimates both short-run and long-run dynamic relationships simultaneously; allows for a distinction between dependent and explanatory variables for the testing of the existence of a long run relationship among variables; and can be applied even when the variables have differing optimal number of lags. The $A R D L$ estimation assumes that all variables are endogenous; therefore, equation (18) estimates the money demand function.

$$
\begin{gathered}
\Delta \ln \left(\frac{M}{P}\right)_{t}=\alpha_{0}+\sum_{j=1}^{P} \beta_{j} \Delta \ln \left(\frac{M}{P}\right)_{t-j}+\sum_{j=0}^{P} \delta_{j} \Delta \ln Y_{t-j}+\sum_{j=0}^{P} \theta_{j} \Delta I N F_{t-j}+\sum_{j=0}^{P} \omega_{j} \Delta I R S_{t-j}+\sum_{j=0}^{P} \gamma_{j} \Delta \ln E X P_{t-j}+ \\
\sum_{j=0}^{P} \mu_{j} \Delta F I R_{t-j}+\sum_{j=0}^{P} \tau_{j} \Delta C O B_{t-j}+\sum_{j=0}^{P} v_{j} E U I_{t-j}+K_{1} \ln \left(\frac{M}{P}\right)_{t-1}+K_{2} \ln Y_{t-1}+K_{3} I N F_{t-1}+K_{4} I R S_{t-1}+ \\
K_{5} \ln E X P_{t-1}+K_{6} F I R_{t-1}+K_{7} \operatorname{COB}_{t-1}+K_{8} E U I_{t-1}+\varepsilon_{t}
\end{gathered}
$$

Where $\Delta$ denotes the first difference operator, $\alpha_{0}$ is the drift component and $\varepsilon_{t}$ denotes the white noise residual. The first term of the summation on the right-hand side sums up the differences of monetary aggregates starting from the first lag whereas the other summations on the independent variables sum up the differences of the independent terms from the zero lag. The differences terms estimate the short run effects while the variables in their levels estimate the long run effects. Equation 19 is the standard $V A R$ model of lagged level variables linearly combined and added as proxy for lagged error terms which measures the departure variable from the independent variable as expressed in equation 18.

The presence of a long run relationship under $A R D L$ is tested using the $F$-test which determines the joint significance of lagged levels of the variable involved. The $\mathrm{F}$-test involves two sets of asymptotic critical values (Peseran et al., 2001). The lower critical bound assumes all the variables are $I(0)$ and therefore there is no cointegrating relationship between the examined variables, whereas the upper bound assumes that all the variables are $I$ (1) meaning that there is no cointegration among the variables.

The error correction $A R D L$ equation is then given as in equation 20 below;

$$
\begin{gathered}
\ln \left(\frac{M}{P}\right)_{t}=\alpha_{0}+\sum_{j=0}^{P} \beta_{j} \Delta \ln \left(\frac{M}{P}\right)_{t-j}+\sum_{j=0}^{P} \delta_{j} \Delta \ln Y_{t-j}+\sum_{j=0}^{P} \theta_{j} \Delta I N F_{t-j}+\sum_{j=0}^{P} \omega_{j} \Delta I R S_{t-j}+\sum_{j=0}^{P} \gamma_{j} \Delta \ln E X P_{t-j}+ \\
\sum_{j=0}^{P} \mu_{j} \Delta F I R_{t-j}+\sum_{j=0}^{P} \tau_{j} \Delta C O B_{t-j}+\sum_{j=0}^{P} v_{j} \Delta E U I_{t-j}+\sigma_{j} E C T_{t-1}+\varepsilon_{t}
\end{gathered}
$$

$\sigma_{j}$ is the speed of adjustment parameter and the error correction term, ECT captures the residuals obtained from the estimated equation. 


\section{Data}

This paper uses quarterly data spanning a period of seventeen years from $2001 Q 4$ to $2017 Q 2$. The data is collected from multiple sources that is: quarterly GDP data is obtained from the rebased Uganda Bureau of Statistics (UBOS) series; monetary aggregates' data, Inflation, exchange rate and interest rates are obtained from Bank of Uganda. Earlier GDP series were rebased so as to match with the recently rebased UBOS data series. The London Interbank Offered Rate $(L I B O R)$ which is the measure of foreign interest rate is obtained from the Federal Reserve of St. Louis. The $\angle I B O R$ is used as a foreign interest rate proxy because it is a composite of the world's major currencies and it also recognizes that the Uganda exchange rate is highly influenced by variations in the USA Dollar. The measure of financial development $(C O B)$ is calculated as a ratio of currency outside banks to time deposits using data obtained from Bank of Uganda. As earlier hinted on, Uganda's economic uncertainty indicator is calculated from the GARCH series of various indicators like: economic activity, exchange rate, interest rates, inflation, foreign interest rates and financial development. Money and GDP are both estimated in their real and log forms. This paper also uses the interest rate spread (IRS) instead of the individual rates; it does this by assuming an equal elasticity in absolute terms for both the 91-day Treasury bill rate and the time and savings deposit rate. The descriptive statistics are as shown in Annex 1.

\subsection{Correlation Analysis}

The correlation results show that there are somewhat higher correlations between money demand with some variables, like: exchange rate, economic uncertainty index; financial innovations proxy; and inflation for all the three monetary aggregates. Additionally, money demand is negatively related to foreign interest rate, financial innovations and the interest rate spread. The other variables that are highly correlated are: inflation and exchange rate; exchange rate and financial innovations; exchange rate and uncertainty index; and inflation and financial innovations. The created economic uncertainty index shows that it is highly related to money demand, exchange rate, inflation and financial innovations. The somewhat high correlations are expected especially in money demand models (Guloba and Osoro, 2009). The high correlations are partly due to the fact that all the data is taken for a period during financial liberalization where these variables express the same characteristics and are trending in time. Omitting any of these key variables from the model will lead to omitted variable bias and this will have negative effects on the estimation results. So, in such cases, economic theory takes precedence. Also, regression estimations using first differences helps to deal with multicollinearity since as it removes the trend component from the times series; this is partly accounted for in the $(A R D L)$ estimation method that has been used since it includes a number of differences within its framework. Moreover, extending the correlation of variables analysis to the secondary stage of the first differences shows that the correlations among the predictor are low and these are more meaningful especially in the short run analysis.

\subsection{Unit Root Testing}

Unit root testing is done using the Dickey Fuller Generalized Least Squares (DFGLS) by Elliot et al. (1996) because of its superiority in power over small samples. The DFGLS unit root is deemed to have significantly greater power than the ordinary Dickey Fuller 1979 and Phillips Perroni 1988 tests. In essence, DFGLS test is the Dickey Fuller test except that the time series is transformed via a generalized least squares regression before performing the test. The $D F G L S$ is therefore performed analogously but on a GLS- detrended data. Whereas the ARDL allows for the estimation of variables with a mixed level of integration, it necessitates that variables are not integrated of order 2.

Unit root results as shown in Annex 2 reveal that $L R B M, L R M 2, L R M 3$ and IRS are integrated of order one I(1) while $L R G D P, L E X P, I N F, C O B, F I R$ and $E U I$ are integrated of order zero $I(1)$. Additionally, the variable graphs show that $L R B M, L R M 2$ and $L R M 3$ are trending upwards while $I R S$ is a fluctuating graph. However, their first differences are mean reverting and therefore no unit root exists. The presence of variables that have different orders of integration and the absence of a variable integrated of order two $I(2)$ necessitate for the estimation of the money demand models using $A R D L$ methodology. The $A R D L$ methodology has other advantages over the traditional cointegration of Engle and Granger (1987) and Johansen and Juselius (1990). This is because it can be applied on a small sample size; simultaneous estimation of both short-run and long-run dynamic relationships can be done; can be applied when the variables have differing optimal number of lags; and allows for a distinction between dependent and explanatory variables for the testing of the existence of a long run relationship between the variables.

\section{Results and Discussion}

\subsection{Lag Length Selection Criteria}

The ARDL approach allows variables to have different optimal lag length. The lag length selection criteria are determined by following the Akaike Information Criteria $(A I C)$. The different lag length for the three money demand models following the specification as (LGDP, LEXP, INF, COB, FIR, EUI, IRS) are: $(3,4,4,4,4,4,4,2)$ for $L R B M$; $(4,4,4,3,4,4,4,2)$ for $L R M 2$ and $(2,2,4,2,3,3,3,2)$ for $L R M 3$. The AIC chooses the best fit model from a number of possible models and it selects the three models as the best. 


\subsection{F-Bounds Cointegration Test}

The F-Bounds cointegraton is done based on the preliminary estimation results so as to verify the existence of a long-term relationship between money and its relationships. All the three models satisfy the existence of a long-term relationship because the $\mathrm{F}$-test is above the upper bound at all levels of significance, as shown in Annex 2. This therefore necessitates the estimation of the $A R D L$ models at the second stage to obtain both the long term and short run results.

\subsection{Long Run Estimations}

Table 1. Long run results

\begin{tabular}{llll}
\hline Variable & \multicolumn{3}{l}{ Coefficient (Standard error) } \\
\cline { 2 - 4 } & LRBM & LRM2 & LRM3 \\
\hline LGDP & $0.878^{* * * *}(0.189)$ & $0.930^{* * *}(0.255)$ & $0.979^{* * *}(0.173)$ \\
LEXP & $-1.569^{* * *}(0.002)$ & $-1.64 * *(0.638)$ & $-0.658(0.474)$ \\
INF & $0.002^{* * *}(0.0007)$ & $0.002(0.001)$ & $0.004^{* * *}(0.474)$ \\
COB & $-1.832^{* * *}(0.257)$ & $-2.700^{* * *}(0.435)$ & $-2.353^{* * *}(0.278)$ \\
FIR & $0.023^{* *}(0.009)$ & $0.035^{* *}(0.014)$ & $0.046^{* * *}(0.012)$ \\
IRS & $-0.021^{* *}(0.008)$ & $-0.023^{*}(0.012)$ & $0.011(0.009)$ \\
EUI & $0.000^{* * *}(0.000)$ & $0.000^{* * *}(0.000)$ & $0.000^{* *}(0.000)$ \\
\hline
\end{tabular}

Notes: (1). The coefficients are tabulated and the standard deviations are included in parentheses; (2). ** and *** denotes significance levels at $5 \%$ and $1 \%$ respectively.

Results in table 1 show that in the long run, increased economic uncertainty has no effect on all monetary balances; $L R B M, L R M 2, L R M 3$. The explanation for this is that: in the long run economic agents (both households and firms) have taken care of the effects or shocks of economic uncertainty; and therefore, their money demand is unaffected. A different explanation could be that the effect of this economic uncertainty is infinitely small to affect monetary balances.

The income elasticity of money demand in the long run is close to unity for all the three money demand estimations; with $0.88,0.93$ and 0.98 for $L R B M, L R M 2, L R M 3$ respectively. The income elasticity results are beyond the 0.5 theoretical stipulations of the Baumol model.

Economic agents will reduce their demand for money whenever the interest rate spread between Treasury bill rates and the time and saving deposit rates increases. This will be done to benefit from the increased returns of holding treasury bills over saving deposits. However, this effect is small and is only significant for real base money (LRBM) and real broad money M2 (LRM2).

The exchange rate result shows that economic agents reduce their money holdings whenever there is depreciation of the Uganda shillings in respect to the US Dollar; however, this is only significant for real base money ( $L R B M)$ and real broad money M2 (LRM2).

An increase in inflation leads economic agents to hold more money for real base money (LRBM) and real broad money M2 (LRM2). Additionally, economic agents increase their monetary holdings for all the three monetary aggregates whenever there is an increase in the foreign interest rate. They therefore would prefer to consume instead of further saving. Lastly, the increase in financial innovations economic agents to hold their money for all the three monetary aggregates instead of saving. 


\subsection{Short run Estimations}

Table 2. Short run results

\begin{tabular}{|c|c|c|c|}
\hline \multirow[t]{2}{*}{ Variable } & \multicolumn{3}{|l|}{ Coefficient (Standard error) } \\
\hline & $\operatorname{LRBM}(3,4,4,4,4,4,4,2)$ & LRM2 $(4,4,4,3,4,4,4,2)$ & $\operatorname{LRM3}(2,2,4,2,3,3,3,2)$ \\
\hline$E C T$ & $-0.848 * * *(0.109846)$ & $-0.539 * * *(0.081)$ & $-0.497 * * *(0.061)$ \\
\hline$D(\operatorname{LRBM} M(-1))$ & $-0.362 * * *(0.098702)$ & $-0.516 * * *(0.116)$ & $-0.236 * *(0.105)$ \\
\hline$D(\operatorname{LRBM}(-2))$ & $-0.265967 * *(0.100725)$ & $-0.357 * *(0.129)$ & \\
\hline$D(\operatorname{LRBM} M(-3))$ & & $-0.238 * *(0.089)$ & \\
\hline$D(L G D P)$ & $0.647007 * * *(0.107987)$ & $0.444 * * *(0.098)$ & $0.238 * * *(0.061)$ \\
\hline$D(L G D P(-1))$ & $0.107(0.0996)$ & $0.147(0.087)$ & $-0.136 * *(0.060)$ \\
\hline$D(L G D P(-2))$ & $0.299 * * *(0.0976)$ & $0.181 * *(0.084)$ & \\
\hline$D(L G D P(-3))$ & $0.479 * * *(0.112)$ & $0.344 * * *(0.098)$ & \\
\hline$D(L E X P)$ & $-0.088(0.087)$ & $-0.019(0.081)$ & $0.187 * *(0.074)$ \\
\hline$D(\operatorname{LEXP}(-1))$ & $0.874 * * *(0.222)$ & $0.328(0.209)$ & $0.334 *(0.175)$ \\
\hline$D(\operatorname{LEX} P(-2))$ & $0.859 * *(0.347089)$ & $0.367(0.292)$ & $-0.232(0.181)$ \\
\hline$D(\operatorname{LEXP}(-3))$ & $-0.975 * * *(0.193)$ & $-0.528 * * *(0.160)$ & $-0.282 * * *(0.093)$ \\
\hline$D(I N F)$ & $-0.001(0.0007)$ & $-0.003 * * *(0.0008)$ & $-0.003 * * *(0.176)$ \\
\hline$D(\operatorname{INF}(-1))$ & $-0.002 * *(0.0008)$ & $-0.003 * * *(0.0008)$ & $-0.002 * * *(0.0007)$ \\
\hline$D(I N F(-2))$ & $-0.0009(0.0008)$ & $-0.002 *$ & \\
\hline$D(\operatorname{INF}(-3))$ & $0.002 * * *(0.0006)$ & & \\
\hline$D(C O B)$ & $0.457 * * *(0.098)$ & $-0.014 * * *(0.901)$ & $-0.103(0.080)$ \\
\hline$D(\operatorname{COB}(-1))$ & $1.883 * * *(0.300)$ & $1.182 * * *(0.250)$ & $0.712 * * *(0.133)$ \\
\hline$D(\operatorname{coB}(-2))$ & $1.427 * * *(0.229)$ & $0.814 * * *(0.192)$ & $0.459 * * *(0.090)$ \\
\hline$D(\operatorname{coB}(-3))$ & $0.661 * * *(0.174)$ & $0.402(0.147)$ & \\
\hline$D(F I R)$ & $-0.004 * * *(0.009)$ & $-0.010(0.008)$ & $-0.031 * * *(0.006)$ \\
\hline$D(F I R(-1))$ & $-0.050 * * *(0.011535)$ & $-0.040 * * *(0.010)$ & $-0.036 * * *(0.009)$ \\
\hline$D(F I R(-2))$ & $-0.042 * * *(0.009)$ & $-0.024(0.008)$ & $-0.024 * * *(0.008)$ \\
\hline$D(F I R(-3))$ & $-0.069 * * *(0.015)$ & $-0.038 * * *(0.013)$ & \\
\hline$D(I R S)$ & $-0.007 * * *(0.002)$ & $-0.005 * *(0.002)$ & $-0.0009(0.002)$ \\
\hline$D(\operatorname{IRS}(-1))$ & $0.011 * * *(0.002)$ & $0.007 * * *(0.002)$ & $-0.006 * * *(0.002)$ \\
\hline$D(\operatorname{IRS}(-2))$ & $0.010 * * *(0.002)$ & $0.008 * * *(0.002)$ & $-0.005^{* *}(0.002)$ \\
\hline$D(\operatorname{IRS}(-3))$ & $0.007 * * *(0.002)$ & $0.006 * *(0.002)$ & \\
\hline$D(E U I)$ & $0.000(0.000)$ & $0.000 * *(0.000)$ & $-0.000(0.000)$ \\
\hline$D(E U I(-1))$ & $-0.000(0.000)$ & $-0.000 * * *(0.000)$ & $-0.000 *(0.000)$ \\
\hline C & $12.451 * * *(1.609)$ & $8.161 * * *(1.220)$ & $3.002 * * *(0.363)$ \\
\hline$R^{2}$ & 0.995 & 0.953890 & 0.942203 \\
\hline Adjusted $R^{2}$ & 0.883 & 0.878437 & 0.888259 \\
\hline$F$-statistics & $13.199 * * *$ & $12.64217 * * *$ & $805.478 * * *$ \\
\hline S.E. of Regression & 0.025 & 0.023371 & 0.021966 \\
\hline Squared-Residual sum & 0.0138 & 0.012016 & 0.014475 \\
\hline$D W$ & 2.319 & 2.264115 & 2.245631 \\
\hline Breush-Godfrey Test & $3.829(0.0391)$ & $3.164703(0.064)$ & $1.008(0.378)$ \\
\hline Arch-Heteroscedasticity & $0.907(0.354)$ & $0.049694(0.824)$ & $2.997(0.901)$ \\
\hline$J B$ Normality test & $6.715(0.035)$ & $5.016(0.081)$ & $1.585(0.453)$ \\
\hline
\end{tabular}

Notes: (1). *, ** and *** represent $10 \%, 5 \%$ and $1 \%$ levels of significance respectively; (2). Coefficients are tabled whereas number in parentheses are the standard errors. However, the number in parentheses for diagnostic tests represent probabilities.

The error correction terms for the three monetary aggregates are negative and statistically significant; that is; -0.85 , -0.54 and -0.5 for real base money, real broad money $M 2$ and real broad money $M 3$ respectively. 85 percent of disequilibrium in the long run relationship of real base money is corrected in the next quarter. 54 percent of disequilibrium in the long run for real $M 2$ is corrected for in the next quarter and similarly 50 percent of long term disequilibrium in real broad money $M 3$ is corrected for in the next quarter.

The results also show that economic uncertainty doesn't have an effect on real base money and real broad money M2 (and in case it exists, it is positive and infinitely small). This means that economic agents' monetary balances are not affected by unforeseen expenditures and future uncertainties (At best, they will increase their monetary holding by a very small magnitude). However, economic agents decrease their monetary holdings for the real broad money M3. This is expected because they will diversify their monetary holding in long term accounts and foreign accounts. This is because economic agents will need money later on in the future to act as cushion of the unforeseen uncertainties. 
An additional effect of economic uncertainty on monetary aggregates comes after one lag (quarter) and is negative for all the three monetary aggregates. Economic agents have by this time formed expectations and therefore save some of their monetary aggregates to compensate for future uncertainties. One other reason for the behavior of economic uncertainties is that the Ugandan economy still has shallow capital markets; only a few economic agents participate in the Bills and Bonds market and there exist low long-term saving. Ultimately, estimation of Uganda's monetary policies will constitute more of monetary aggregates, near monetary instruments and a few long-term instruments. The elements of economic uncertainty are somehow taken care of by the economic agents in terms of their choice of monetary holdings.

The income elasticity of monetary balances is $0.65,0.44$ and 0.24 for real base money, real broad money $M 2$ and real broad money $M 3$ respectively. The income elasticity results for real base money and real broad money $M 2$ are not so different from the 0.5 theoretical stipulations of Baumol model. This therefore shows that policies directed

towards economic agents' income (LRBM) and (LRM2) will have a very effective impact for all the three monetary aggregates.

The increase in the interest spread between the treasury bill rate and the deposit and saving rate leads economic agents to reduce their monetary holdings for real base money ( $L R B M)$ and real broad money (LRM2). The reason for this is to enjoy the increased returns that accrue to the holding treasury bills than the saving and deposit rate. However, these coefficients switch signs to become positive starting from the first lag (quarter). Economic agents are no longer entirely enticed to enjoy returns from the treasury bill-savings and deposit rate spread; they therefore hold their money balances or diversify their holdings into land and mortgages.

The economic agents reduce their monetary holdings whenever there is an exchange rate depreciation for the three monetary aggregates. The result satisfies the notion that a weak domestic currency yields expectation for further weakening, and therefore asset holders shift some of their portfolios away from domestic currency into foreign currency.

In the short run, the increase in inflation makes economic agents to reduce their monetary holdings. They diversify their portfolio into other forms like buying mortgages, land, foreign accounts among others so as to act as a precaution against the reducing purchasing of money. Similarly, economic agents reduce their monetary holdings whenever there is increase in the foreign interest rate; this is expected since they would want to enjoy the higher returns that accrue to holding foreign accounts.

Lastly, financial innovation increases money holdings in the short run for real base money but reduces them for real broad money $M 2$. This is because economic agents can easily translate their bank deposits into consumable balances for real base money M1 since it is a composition of currency and bank deposits. However, money holdings decrease for real broad money $\mathrm{M} 2$ because economic agents are holding long term savings and deposits.

\subsection{Diagnostic Tests}

The results show that the money demand models are well specified. The Breusch Godfrey and the Arch-heteroscedasticity tests fail to find serial correlation and heteroscedasticity for the models respectively at the one percent level of significance. The Jacque Bera normality test is also satisfied at the one percent level of significance.

\subsection{Stability Tests}

Three stability tests are used for this paper, i.e.; the recursive estimate ordinary least square tests of residual estimate, CUSUM and CUSUMQ tests. Majorly all the three stability tests satisfy for stability of money demand during the period of estimation. The only instabilities appear in real broad money $M 2$ and real broad money during $2012 Q 2$ and $2016 Q 1$ as manifested in the recursive residuals tests. This could highly be attributed to the various financial innovations.

\section{Conclusions and Policy Implications}

This paper has examined the relationships between economic uncertainty and money demand in Uganda. Whereas many traditional money demand models have been carried out, few have been done on the East African region and none for Uganda in particular. This leaves a gap in both policy and literature aspects regarding the effects economic uncertainty on money demand and its stability. This paper therefore provides novel insights into money demand dynamics in Uganda.

The error correction terms are highest for the real base money, medium for real broad money $M 2$ and lowest for real broad money $M 3$. Therefore, monetary policy should currently target real base money and real broad money $M 2$. The short run results reveal that economic uncertainty doesn't have any effect on real base money and real broad money (or it is infinitesimal if at all it exists) but rather decrease their monetary holdings for the real broad money $M 3$. This can also be explained in relationship to the Ugandan capital and mutual funds which are still shallow and under developed. 
This also means that economic agents have already formed expectations for real base money and real broad money $M 2$ and have already taken them into account; however, they tend to diversify their wealth into various other forms when it comes to the real broad money M3. This could be in terms of long term accounts, foreign accounts, mortgages, property and land among others. Interestingly, the effect of economic uncertainty on money demand changes to negative after one lag (one quarter). The economic agents diversify their portfolio holdings after the effect of economic uncertainty has materialised after one quarter has elapsed. In a way, past trends inform action in the next periods and therefore economic agents react adaptively.

Income elasticity of money demand is close to unity in the long run but near 0.5 in the short run for both the real base money and real broad money $M 2$. This satisfies the theoretical specifications of 0.5 by the Baumol model. Additionally, the increase in the interest rate spread between the treasury bill rate and the deposit and saving interest rate causes economic agents to decrease their monetary holdings. Therefore, monetary policy should be oriented toward intensifying the treasury bills and bond markets.

Financial innovation also affects monetary aggregates differently in the short run, that is; increases monetary holdings for real base money but reduces them for real broad money $M 2$. This is due to the fact that different components constitute the two monetary aggregates with real base money being shallow as compared to the broader $M 2$ that includes even long-term components. Other factors like inflation, exchange rate and foreign interest rate significantly affect the economic agents' decision as regards money demand. Generally, all the three-money demand estimation are stable during the period of estimation save for a few temporal instabilities in real broad money M2 during 2012Q4; and real broad money $M 3$ during $2016 Q 1$.

The paper reveals that economic uncertainty affects money demand, therefore, Uganda's Government and Bank of Uganda in particular should tailor encompassing policies that account for economic uncertainty. If accounted for, policies can help in the reallocation of resources from the unproductive sectors to the highly productive sectors which will spur growth to the desired levels; if not accounted for, money demand functions will be poorly specified and thus having a negative toll on economic growth, production, employment and overall economic development.

\section{References}

Anderson, R. G., Bordo, M., \& Duca, J. (2016). Money and velocity during financial crises: from the Great Depression to the Great Recession. Economics Working Paper 16111, Hoover Institution, Stanford University. https://doi.org/10.3386/w22100

Attah, M. J. (2004). Money demand and economic uncertainty. Bank of Canada working Paper 25.

Bahmani, O. M., Bahmani, S., Kones, A., \& Kutan, A. M. (2015). Policy uncertainty and the demand for money in the UK. Applied Economics, Volume 47- Issue 15.

Bahmani, O. M., Ali, M. K., \& Xi. (2013). The impact of economic and monetary uncertainty on the demand for money in Emerging Economies. Applied Economics.

Bank of Uganda. (2017). Bank of Uganda Annual Supervision Report. Bank of Uganda.

Basu, B., \& Bundick B. (2015). Uncertainty shocks in a model of effective demand. Research Working Paper, Federal Reserve Bank of Kansas City

Bloom, N. (2009). The impact of uncertainty shocks. Econometrica,77(3), 623-685. https://doi.org/10.3982/ECTA6248

Bloom, N., Kose, M. A., \& Terrone, M. E. (2013). Held back by uncertainty. Finance and Development, 38-41.

Bollerslev, T. (1986). Generalized Autoregressive Conditional Heterescedasticity. Journal of Econometrics, 307-327. https://doi.org/10.1016/0304-4076(86)90063-1

Bollerslev, T., Chou, R. Y., \& Kroner, K. F. (1992). ARCH modelling in Finance: A Review of the theory and empirical evidence. Journal of Econometrics, 5-59. https://doi.org/10.1016/0304-4076(92)90064-X

Bossone, B. (2014). Secular Stagnation. Economics Discussion Paper.

Bruggeman, A., Donati, P., \& Warner, A. (2003). Is the demand for Euro Area M3 Stable? ECB Working Paper 255.

Carpenter, S. B., \& Lange, J. (2003). Money demand and equity markets. Finance and Economics Discussion Series (Washington Board of Governors of the Federal Reserve System). https://doi.org/10.2139/ssrn.386840

Cartstensen, K., Hagen, J., Hossfield, O., \& Neaves A. S. (2008). Money demand stabilty and inflation prediction in the four largest EMU countries. Kiel Working Papers.

Choi, W. G., \& Oh, S. (2003). A money demand function with output uncertainty, monetary uncertainty and financial innovations . Journal of Money, Credit and Banking , 35(5), 685-709. https://doi.org/10.1353/mcb.2003.0034 
Cronin, D., \& Kennedy, B. (2007). Does uncertainty impact money growth? Central Bank and Financial services Authority of Ireland.

Davidson, L. (1999). Uncertainty in Economics. In: Davidson L. (eds) Uncertainty, International Money, Employment and Theory. Palgrave Macmillan, London. https://doi.org/10.1007/978-1-349-14991-9_2

Dib, A. (2003). Monetary policy in estimated models of small open and closed Economies. Bank of Canada-Working Paper 2003-27.

Eggertsson, G. B., \& Mehrotra, N. R. (2014). A model of secular stagnation. NBER Working Paper No. 20574. https://doi.org/10.3386/w20574

El-Rasheed, S., Abdullah, H., \& Dahalan, J. (2017). Monetary uncertainty and demand for money stability in Nigeria: An Autoregressive Distributed Lag Approach. International Journal of Economics and Financial issues, 7(1), 601-607.

Engle, R. F., \& Bollerslev, T. (1986). Modelling the persistence of conditional variances. Economic Reviews, 5(1). https://doi.org/10.1080/07474938608800095

Friedman, M., \& Schwartz, A. J. (1982). Monetary trends in the United States and the United Kingdom: Their relation to income, Prices, and Interest Rates.1867-1975. University of Chicago Press. https://doi.org/10.7208/chicago/9780226264257.001.0001

Goldman, S. M., \& Sichel, D. E. (1990). "The demand for money: In Handbook of Monetary Economics".

Greiber, C., \& Lemke, W. (2005). Money demand and Macroeconomic Uncertainty. Discussion paper series 1, Economic Studies.

Groessl, I., \& Tarassow, A. (2015). A microfounded model of money demand under uncertainty, and its empirical validation using co integration and rolling windows dynamic multiplier analysis. Universtat Hamburg.

Guloba, A., \& Osoro, N. (2009). Determinants and stability of money demand in Uganda during the period of economic liberalization. African Finance Journal: Special Issue 1, 142-161.

Higgins, M. L., \& Manjin, S. (2009). Inflation uncertainty and money demand. Applied Economics letters. https://doi.org/10.1080/13504850701452023

Ireland, P. (1997). A small, structural, quarterly model for monetary policy evaluation. Carnegie-Rochester Conference series on Public Policy, 83-103. Carnegie. https://doi.org/10.1016/S0167-2231(98)00005-0

Ireland, P. (2001). Money's Role in the monetary business cycle. NBER Working Paper No. 8115. https://doi.org/10.3386/w8115

Johansen, S., \& Juselius, K. (1990). Maximum Likelihood Estimation \& Inference on cointegration with application to the Demand for Money. Oxford Bulletin of Economics \& Statistics, 52(2), 169-210. https://doi.org/10.1111/j.1468-0084.1990.mp52002003.x

Kararach, G. (2002). Evidence on the demand for money function in Uganda. UNICEF

Kim, J. (2000). Constructing and Estimating a Realistic Optimizing Model of Monetary Policy. Journal of Monetary Economics, 45, 329-59. https://doi.org/10.1016/S0304-3932(99)00054-9

Kiptui, M. C. (2014). Some empirical evidence on the Stability of Money Demand in Kenya. International Journal of Economics and Financial Issues, 4(4), 849-858.

Kones, A. (2014 ). Impact of monetary uncertainty and economic uncertainty on money demand in Africa. Theses and Dissertations; Paper 629.

Laidler, D. (2013). Reassessing the Thesis of the Monetary History: In a paper based on speaking notes prepared for the Conference Retrospectives on the Great Depression. Conference Retrospectives on the Great Depression. Princeton University.

Leippold, M., \& Matthys, F. (2015). Economic policy uncertainty and the Yield Curve.

Lucas, R. E. (1972). Expectations and the Neutrality of Money. Journal of Economic Theory, 4. https://doi.org/10.1016/0022-0531(72)90142-1

Lioui, A., \& Poncet, P. (2004). General equilibrium and nominal interest rates. Journal of Banking and Finance 28, 1569-1595. https://doi.org/10.1016/S0378-4266(03)00137-7

Machina, M. J. (1989). Choice under Uncertainty; Problems Solved and Unsolved. Journal of Economic Perspectives, 1. https://doi.org/10.1007/978-1-349-20290-4_2 
Matei, M. (2009). Assessing volatility forecasting models; Why GARCH models take the lead. Romanian Journal of Economic Forecasting 4/2009.bg

Nabiddo, W. (2007). The analysis of money demand for Uganda (1986: 1-2003: 4): Economic Policy Research Centre $(E P R C)$.

Nazar, D., Farshid, M., \& Davood, M. (2011). Economic uncertainty- money demand nexus in Iran: Application of the EGARCH model and the ARDL approach. European Journal of Economic Finance and Administrative Sciences.

Ndirangu, L., \& Nyamongo, E. (2015). Financial innovations and their implications for policy in Kenya. Journal of African Economies. https://doi.org/10.1093/jae/eju029

Nyorekwa, E. T. (2007). The demand for money in Uganda under reform period 1986-2005 (Unpublished Masters' thesis). University of University of Dar es Salaam.

Opolot, J. (2007). A re-examination of the demand for money in Uganda: Nature and Implications for monetary policy. The Bank of Uganda Staff Papers Journal, 1(1), 5-32.

Ozdemir K. A., \& Saygili, M. (2013). Economic uncertainty and money demand stability in Turkey. Central Bank of the Republic of Turkey, Working Paper No. 10/15.

Ricardo, D. (1817). On the Principles of Political Economy and Taxation.

Tillman, P. (2017). Monetary policy uncertainty and the response of the yield curve to policy shocks. School of Business and Economics-Phillips-University Marburg.

\section{Appendix}

Annex 1. Descriptive Statistics

\begin{tabular}{lllllll}
\hline Variables & Observations & Mean & $\begin{array}{l}\text { Standard } \\
\text { Deviation }\end{array}$ & Median & Min & Max \\
\hline LRBM & 63 & 23.805 & 0.364 & 23.820 & 23.180 & 24.606 \\
LRM2 & 63 & 24.271 & 0.423 & 24.294 & 23.550 & 25.148 \\
LRM3 & 63 & 24.563 & 0.457 & 24.541 & 23.777 & 25.500 \\
LGDP & 63 & 25.328 & 0.150 & 25.350 & 25.0003 & 25.688 \\
LEXP & 63 & 7.704 & 0.239 & 7.606 & 7.399 & 8.192 \\
$I N F$ & 63 & 144.073 & 49.548 & 144.163 & 77.829 & 237.128 \\
$C O B$ & 63 & 0.773 & 0.145 & 0.655 & 0.504 & 0.967 \\
FIR & 63 & 1.664 & 1.720 & 1.110 & 0.230 & 5.480 \\
$I R S$ & 63 & -0.4095 & 2.441 & -0.372 & -4.727 & 8.238 \\
EUI & 63 & -0.520 & 3484573 & -1684618 & -3304896 & 9431621 \\
\hline
\end{tabular}

Where $L R B M, L R M 2, L R M 3$ are Log of real base money; Log of real M2 and Log of real M3 respectively.

Annex 2. Stationarity Tests

\begin{tabular}{llll}
\hline Variable & \multicolumn{2}{l}{ DFGLS unit root statistics } & Order of Integration \\
\cline { 2 - 3 } & Levels & First Differences & \\
\hline LRBM & 1.325694 & $-7.177990 * * *$ & $\mathrm{I}(1)$ \\
LRM2 & 1.723699 & $-7.318127 * * *$ & $\mathrm{I}(1)$ \\
LRM3 & 1.917620 & $-7.608099 * * *$ & $\mathrm{I}(1)$ \\
LGDP & $-1.425861 * * *$ & $\mathrm{I}(0)$ \\
LEXP & $1.002908^{* * *}$ & & $\mathrm{I}(0)$ \\
$I N F$ & $-0.550223 * * *$ & $\mathrm{I}(0)$ \\
COB & $-0.287359 * * *$ & $\mathrm{I}(0)$ \\
$F I R$ & $-1.157397 * * *$ & $\mathrm{I}(0)$ \\
$I R S$ & -3.446912 & $-1.886752 * * *$ & $\mathrm{I}(1)$ \\
$E U I$ & $0.786411^{* * *}$ & & $\mathrm{I}(0)$ \\
\hline
\end{tabular}

*** Significance of the Elliot-Rothenburg-Stock DF-GLS test statistic at the $1 \%$ level

F-Bounds Test Results

\begin{tabular}{llll}
\hline$K=7$ & LRBM & LRM2 & LRM3 \\
\hline$F$ - Statistics & 5.649 & 4.215 & 6.768 \\
$95 \%$ Bound (Lower, Upper) & $(2.32,3.5)$ & $(2.32,3.5)$ & $(2.32,3.5)$ \\
$99 \%$ Bound (Lower, Upper) & $(2.96,4.26)$ & $(2.96,4.26)$ & $(2.96,4.26)$ \\
\hline
\end{tabular}

Note: The figures in parentheses indicate both the lower and upper bound for the respective levels of confidence. 
Annex 3.
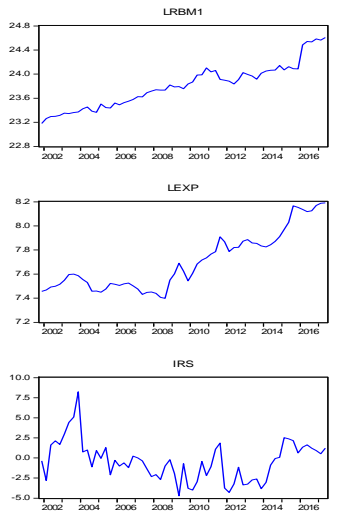
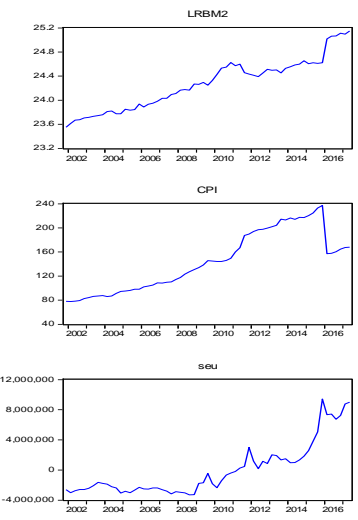
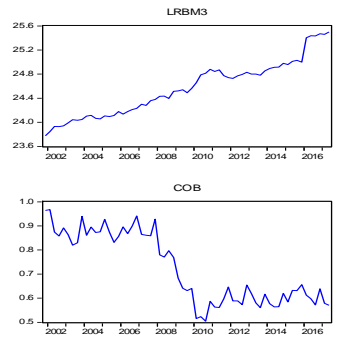
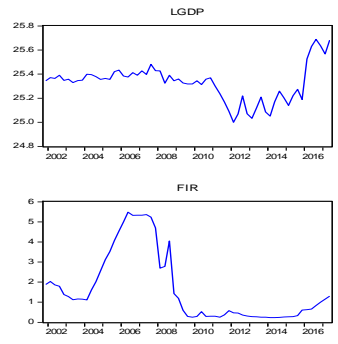

Figure 1. Variable Graphs at levels
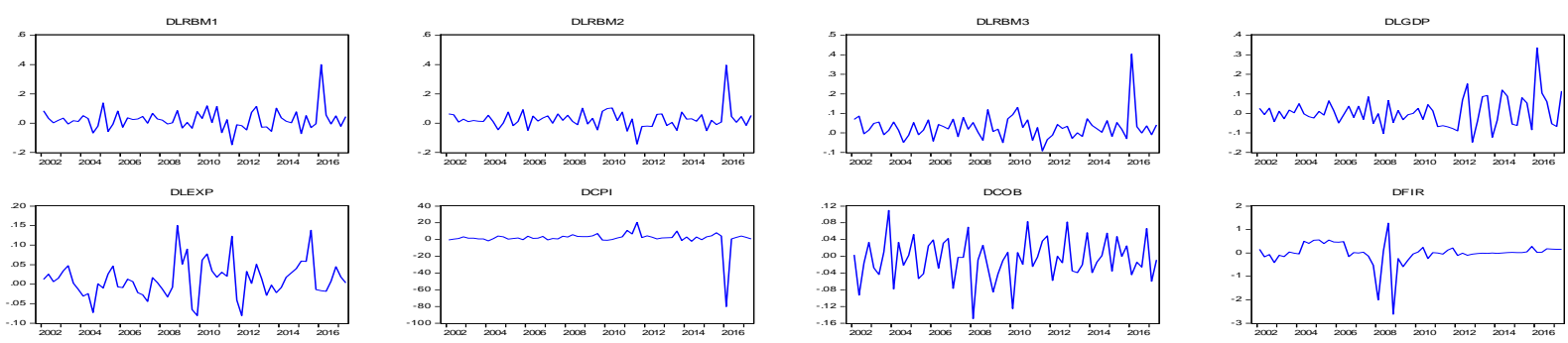

$\mathrm{DCP}$
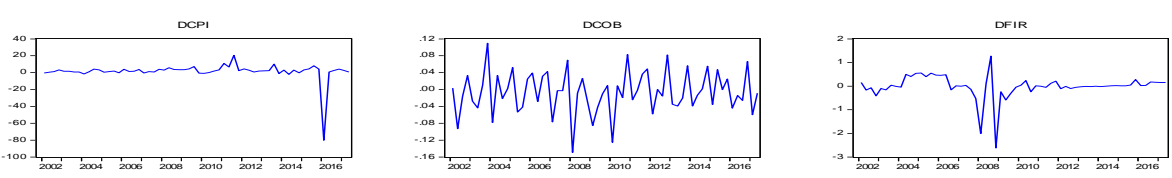

(2001

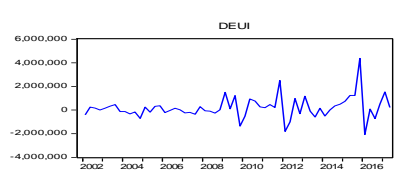

Figure 2. Variable Graphs at First Differences
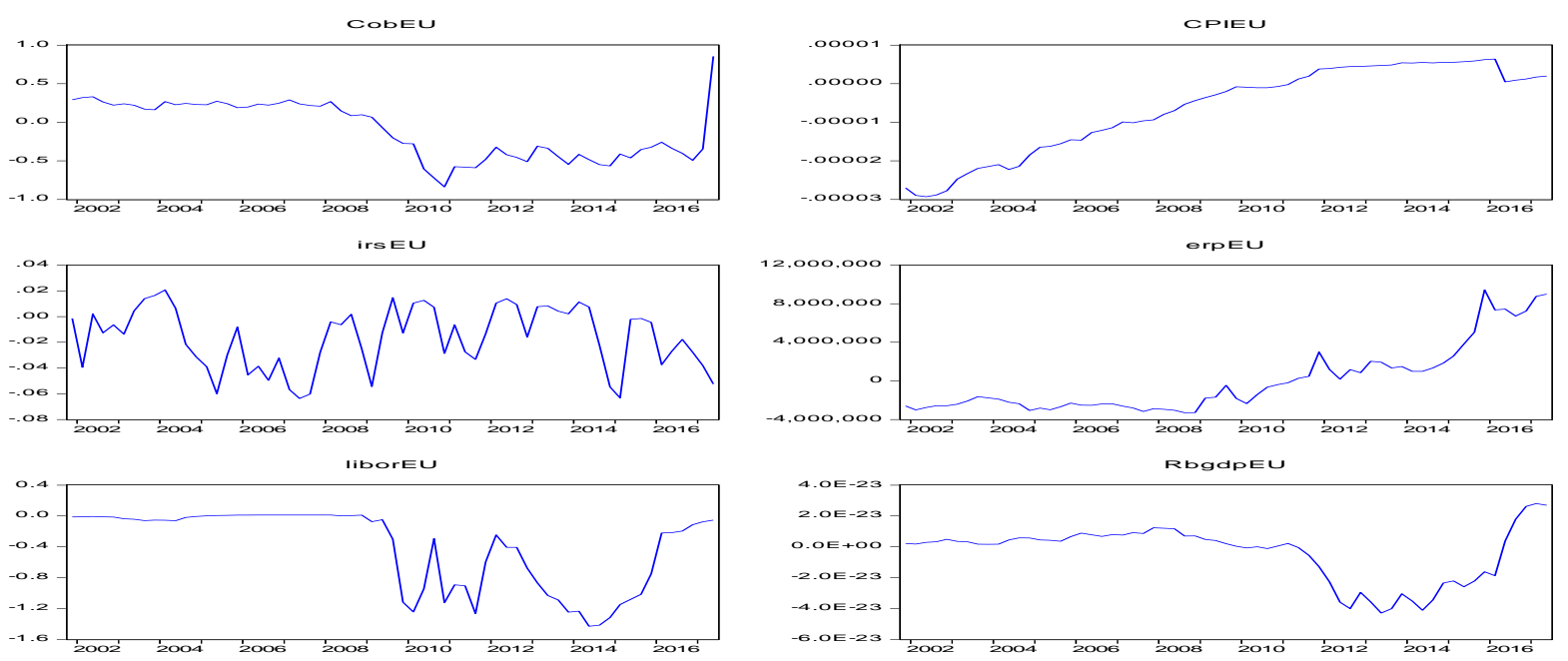

Figure 3. Variable Volatilities 
Recursive residuals - LRBM

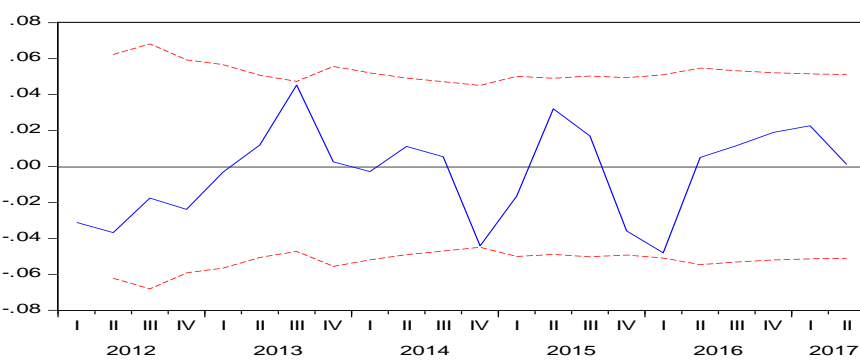

- Recursive Residuals ----- \pm 2 S.E.

\section{CUSUMQ - LRBM}

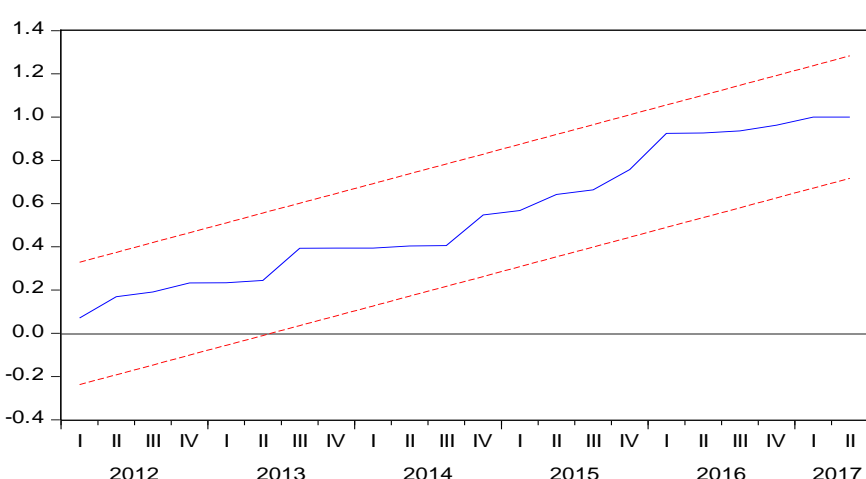

\section{CUSUM - LRM2}

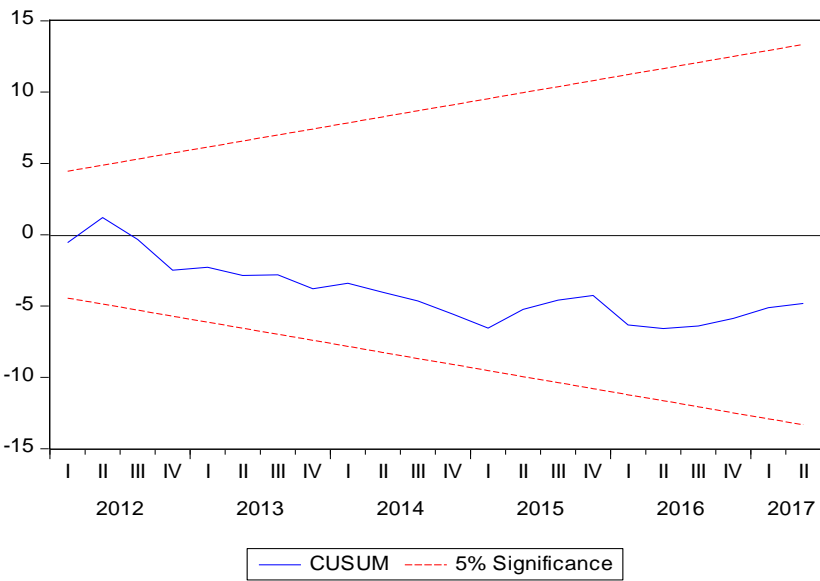

\section{CUSUM-LRBM}

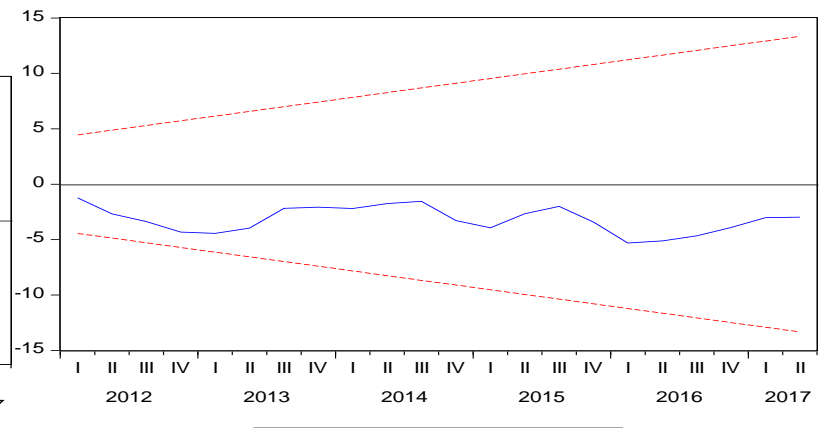

— CUSUM ----. $5 \%$ Significance

\section{Recursive Residuals -LRM2}

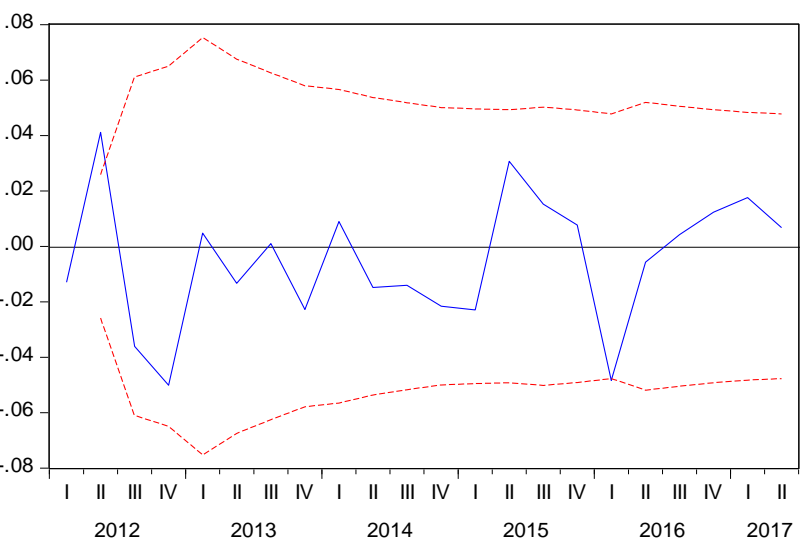

CUSUMQ-LRM2

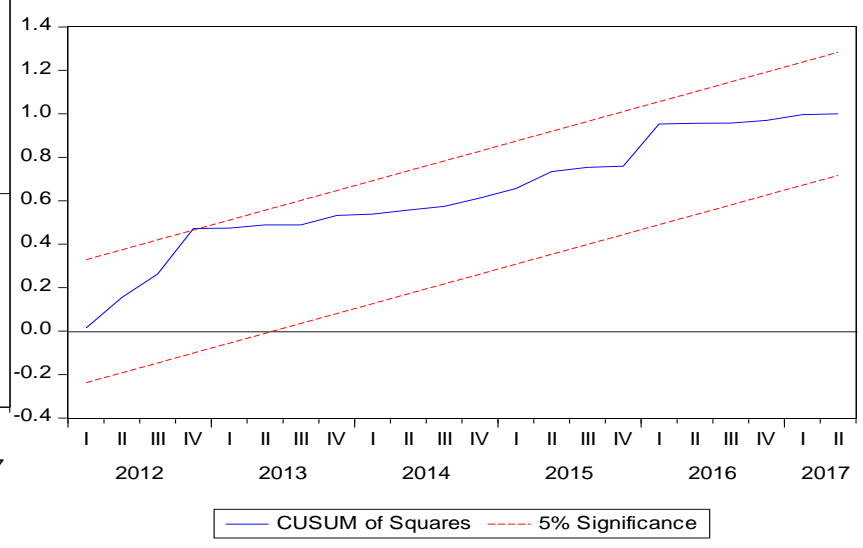




\section{Recursive Residuals - LRBM3}

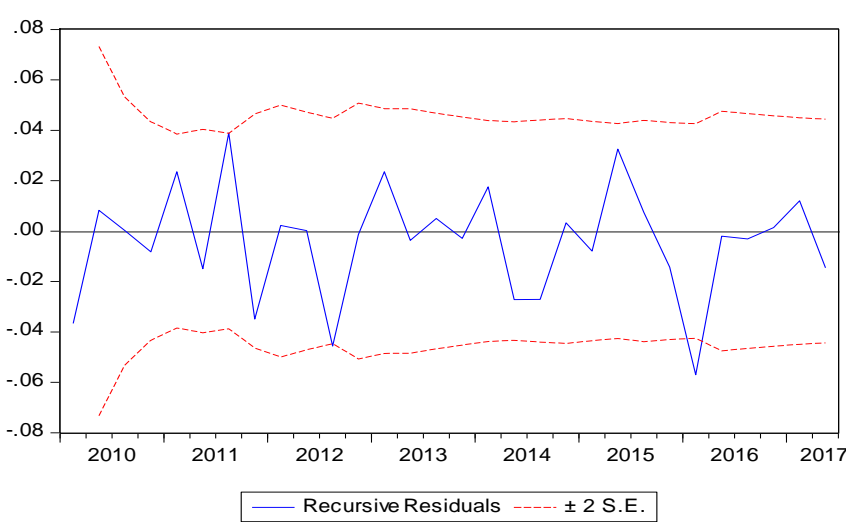

CUSUMQ - LRM3

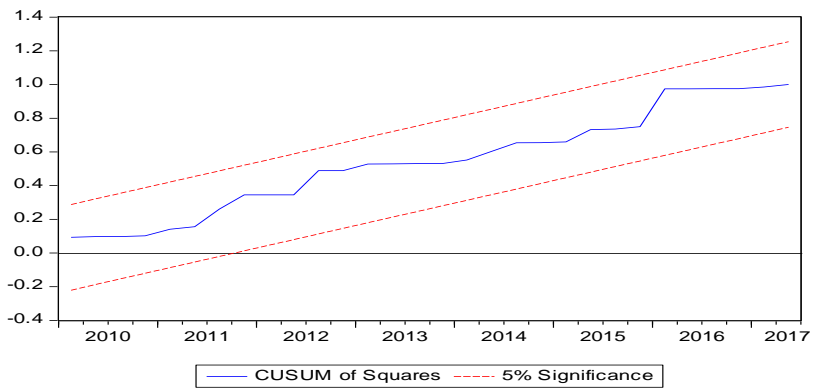

Figure 4. Stability Tests for $\boldsymbol{L R B M}, \boldsymbol{L R M} 2$ and $\boldsymbol{L R M} 3$

Note: The figures above show the stability tests for the three monetary aggregates, LRBM,LRM2 and LRM3 as shown by the recursive residual, CUSUM and CUSUMQ tests.

\section{Copyrights}

Copyright for this article is retained by the author(s), with first publication rights granted to the journal.

This is an open-access article distributed under the terms and conditions of the Creative Commons Attribution license which permits unrestricted use, distribution, and reproduction in any medium, provided the original work is properly cited.

\section{CUSUM-LRM3}

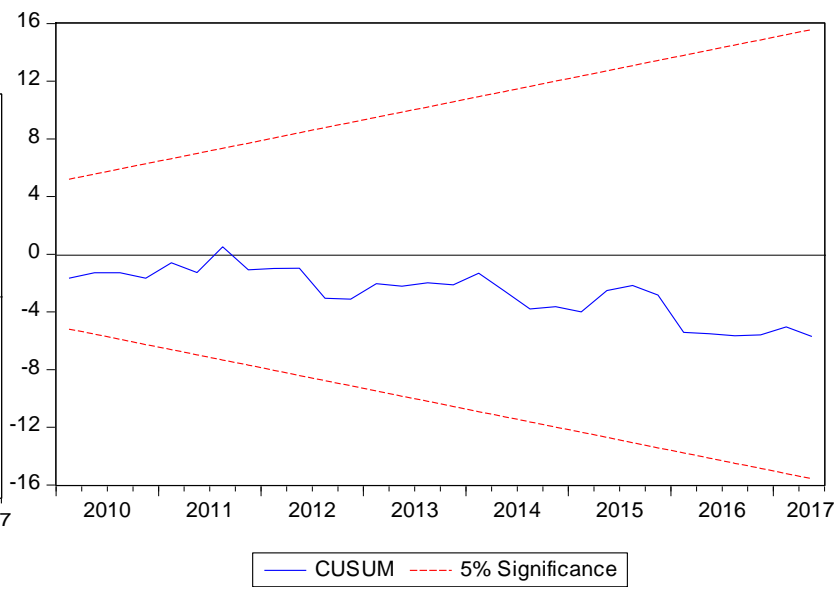

